\title{
STUDY OF VEGETABLE EXTRACTS EFFECT ON WET-WHITE LEATHER
}

\section{Daniela MARTINS ${ }^{1}$, Liliana DUARTE ${ }^{1}$, Vânia F.M. SILVA ${ }^{1 *}$, António CRISPIM ${ }^{1}$, E. BEGHINI², Filipe CRISPIM ${ }^{2,3}$}

${ }^{1} \mathrm{CIETI} /$ ISEP - Centre of Innovation on Engineering and Industrial Technology / IPP School of Engineering, Rua Dr. António Bernardino de Almeida, 831, 4200-072, Porto, Portugal

${ }^{2}$ INDINOR - Indústrias Químicas, SA, Porto, Portugal

${ }^{3} \mathrm{CTIC}$ - Technological Centre for Leather Industry, Alcanena, Portugal

Received: 13.03.2018 Accepted: $16.09 .2018 \quad$ https://doi.org/10.24264/lfj.18.3.6

\section{STUDY OF VEGETABLE EXTRACTS EFFECT ON WET-WHITE LEATHER}

ABSTRACT. Although the worldwide leather production is based on chromium tannage, there is an increasing share of chrome and metal free tannages. This is mainly due to the growing demand for chrome free leathers in the automotive industry. The aim of this work was the study of vegetable extracts effect on the retannage of wet-white leather, produced by the glutaraldehyde and syntan pre-tannage process, evaluating the bath exhaustion and physical-mechanical leather properties. For that, the leather thickness was adjusted to $1.4 \mathrm{~mm}$ and a retanning process was applied to small leather pieces by neutralization, retanning with vegetable extracts, dyeing and fat-liquoring. It was shown that the absorption of vegetable extracts by the leather was greater and faster for the hydrolysable tannins (natural chestnut vegetable extract) than for condensed tannins (mimosa vegetable extract). Different vegetable extracts: natural chestnut, sweetened chestnut, quebracho, gambier, mimosa, tara and cashew, were applied in order to evaluate their effects on leather properties. Properties, as physical-mechanical tests for tear strength, and for ball burst test (to evaluate the grain cracking), and leather behavior regarding softness and grain firmness, were evaluated for the different leather pieces.

KEY WORDS: glutaraldehyde, leather, vegetable extracts, wet-white

\section{STUDIUL INFLUENTEI EXTRACTELOR VEGETALE ASUPRA PIELII WET-WHITE}

REZUMAT. Deși producția de piele la nivel mondial se bazează pe tăbăcirea în crom, există o cotă tot mai mare de procese de tăbăcire fără crom și fără metale. Acest lucru se datorează în principal cererii din ce în ce mai mare de piele fără crom în industria automobilelor. Scopul acestei lucrări a fost studierea influenței extractelor vegetale asupra revitalizării pieilor wet-white, obținute prin procedeul de pre-tăbăcire cu glutaraldehidă și sintani, evaluând gradul de epuizare a flotei și proprietățile fizico-mecanice ale pielii. Pentru aceasta, grosimea pielii a fost ajustată la 1,4 mm și s-a efectuat un proces de retăbăcire a bucăților mici de piele prin neutralizare, retăbăcire cu extracte vegetale, vopsire și ungere. S-a demonstrat că absorbția extractelor vegetale în piele a fost mai mare și mai rapidă în cazul taninurilor hidrolizabile (extract vegetal natural de castan) decât în cazul taninurilor condensate (extract vegetal de mimosa). Au fost folosite diferite extracte vegetale: castan natural, castan îndulcit, quebracho, gambir, mimosa, tara și caju, pentru a evalua efectele acestora asupra proprietăților pielii. S-au evaluat proprietățile diferitelor bucăți de piele prin teste fizico-mecanice pentru a determina rezistența la rupere și rezistența la crăparea feței, precum și comportamentul pielii în ceea ce privește moliciunea și fermitatea feței.

CUVINTE CHEIE: glutaraldehidă, piele, extracte vegetale, wet-white

\section{ÉTUDE DES EFFETS DES EXTRAITS VÉGÉTAUX SUR LE CUIR WET-WHITE}

RÉSUMÉ. Bien que la production mondiale de cuir soit basée sur le tannage au chrome, il y a une part croissante de tannages sans chrome et sans métal. Ceci est principalement dû à la demande croissante de cuirs sans chrome dans l'industrie automobile. Le but de cet article était d'étudier l'effet des extraits végétaux sur le retannage du cuir wet-white, produit par le procédé de pré-tannage au glutaraldéhyde et au syntan, en évaluant l'épuisement du bain et les propriétés physico-mécaniques du cuir. Pour cela, l'épaisseur du cuir a été ajustée à 1,4 $\mathrm{mm}$ et un procédé de retannage a été appliqué aux petites pièces de cuir par neutralisation, retannage avec des extraits végétaux, teinture et graissage. Il a été montré que l'absorption des extraits végétaux par le cuir était plus grand et plus rapide pour les tannins hydrolysables (extrait végétal naturel de châtaigne) que pour les tanins condensés (extrait végétal de mimosa). Différents extraits végétaux: châtaigne naturelle, châtaigne adouci, quebracho, gambier, mimosa, tara et noix de cajou, ont été appliqués afin d'évaluer leurs effets sur les propriétés du cuir. On a évalué les propriétés du cuir par les tests physico-mécaniques pour la résistance au déchirement, et pour l'essai d'éclatement de balle (afin d'évaluer le gerçure de la fleur), et le comportement du cuir en matière de douceur et de fermeté de la fleur.

MOTS CLÉS : glutaraldéhyde, cuir, extraits végétaux, cuir wet-white.

* Correspondence to: Vânia F.M. SILVA, CIETI / ISEP - Centre of Innovation on Engineering and Industrial Technology/IPP School of Engineering, Rua Dr. António Bernardino de Almeida, 831, 4200-072, Porto, Portugal, vfmsi@isep.ipp.pt. 


\section{INTRODUCTION}

The research centers throughout the world have undertaken a lot of work on new tanning process in order to replace the chromium tanning process. Conventional chromium tanning is the most widely process used in the world and generates a significant pollutant load with a reasonable chromium content in the waste water and in the solid wastes. Nevertheless, the process has significant advantages as its high thermal stability [1] and its versatility of end products obtained, very important characteristics for shoe upper leather.

The last few years, wet-white tanning appeared as an alternative to chromium tanning process, mainly for automotive leather, furniture and children's shoes. This process is mainly based on glutaraldehide and a syntan pre-tannage [2]-[4]. After this pre-tannage, the process is followed by thickness adjustment, retanning using polyphenols (vegetable and syntan tanning agents) and other organic-synthetic agents, dyeing and fat-liquoring.
The use of vegetable extracts for wet-blue retannage is a normal way to obtain certain characteristics of the final leather product. Vegetable tannage and vegetable combination tannages have been always used in leather production [5], [6].

In this work, it is studied the effect of vegetable extracts when applied as retanning agents for wet-white leather. For that, a wetwhite based process developed by INDINOR, a Portuguese chemical company, was used.

\section{EXPERIMENTAL}

\section{Materials and Methods}

The raw material used in this work was wet-white leather prepared by INDINOR, a chemical company located at Portugal, using the process showed in the Table 1.

The process was made on bovine pickled pelt (lime spiltted) and chemicals quantity was calculated as $\%$ based on pickled pelt weight.

Table 1: Wet-white pre-tannage process

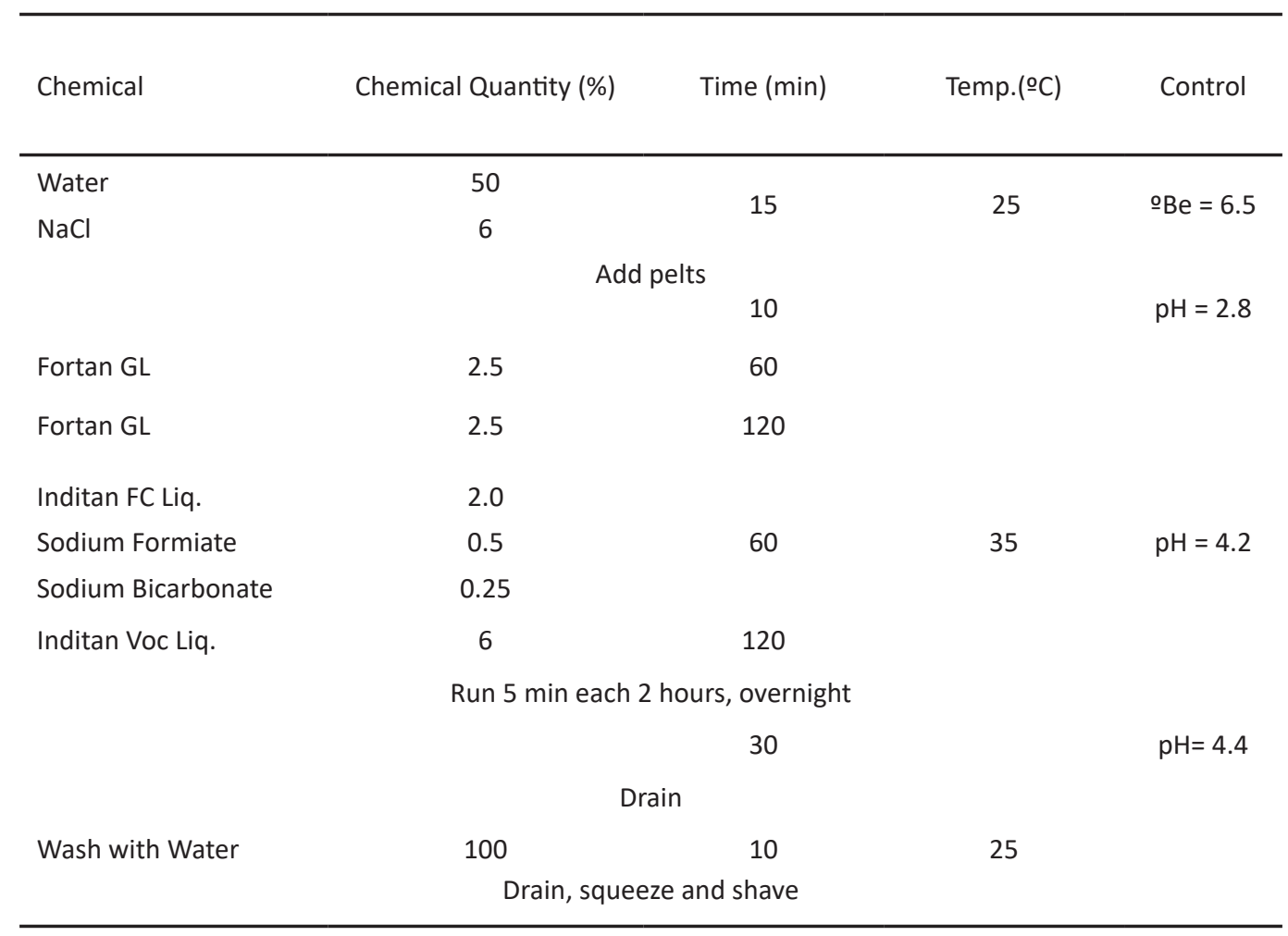


Wet-white leather, thus prepared, was shaved to a thickness of $1.4 \mathrm{~mm}$ in a shaving machine and submitted to the respective process depending on the study in question.

For all the trials, small pieces of wet-white were used, always from the same zone near the back-bone. The chemicals used were all obtained from INDINOR: Fortan GL (gluteraldehyde based); Inditan FC Liq. (masking phtalic salt); Inditan VOC Liq. (synthetic tannin); Indinol BE (natural oil); Indinol HS (emulsion of synthetic fats); Indinol EAF (sulphited fish oil); Indinol LOX (lanolin based oil)

The trials were carried out using laboratory drums (LFA-9293, Mathis), with temperature and speed control and product quantities were based on the weight of wet-white hide pieces used.

\section{Vegetable Extracts Absorption}

The up-take of the vegetable extracts by the leather was studied for hydrolysable tannins (natural chestnut vegetable extract) and condensed tannins (mimosa vegetable extract).

In each trial, wet-white shaved pieces weighing approximately $100 \mathrm{~g}$ were washed with $300 \% \mathrm{w} / \mathrm{w}$ of water at $35 \circ \mathrm{C}$ during $10 \mathrm{~min}$, neutralized with $1.5 \% \mathrm{w} / \mathrm{w}$ of sodium formiate and $0.5 \% \mathrm{w} / \mathrm{w}$ of sodium bicarbonate to $\mathrm{aH}$ of 6 in 200\% w/w of water at 35\% $\mathrm{C}$ and during $30 \mathrm{~min}$, washed again with $300 \% \mathrm{w} / \mathrm{w}$ at $40 \circ \mathrm{C}$ during $10 \mathrm{~min}$, and treated with $12 \% \mathrm{w} / \mathrm{w}$ of vegetable extract, natural chestnut in one case and mimosa in the other, in $200 \% \mathrm{w} / \mathrm{w}$ of water at 40 ㄷ. Samples from the vegetable retanning bath were taken at $1 \mathrm{~min}, 15 \mathrm{~min}, 30 \mathrm{~min}, 60$ min and 120 min of running time, and evaluated to read the absorbance in a spectrophotometer UV-VIS according the method cited in [7].

\section{Vegetable Effect on Leather: Physical and Mechanical Properties}

The effect of vegetable extracts on leather physical mechanical properties was studied for eight vegetable extracts: natural chestnut, sweetened chestnut, mimosa, tara, cashew, gambier and quebracho. For each trial, samples from shaved wet-white pelt, weighting approximately $100 \mathrm{~g}$, were submitted to retanning, dyeing and fat-liquoring process showed in the Table 2.

Table 2: Wet-white retanning, dyeing and fat-liquoring process

\begin{tabular}{|c|c|c|c|c|}
\hline Process & Chemical & Chemical Quantity (\%) & Time (min) & $\mathrm{T}$ (으) \\
\hline \multirow[t]{3}{*}{ Washing } & Water & 300 & 10 & 35 \\
\hline & & Drain & & \\
\hline & Water & 200 & \multirow{3}{*}{30} & \multirow{3}{*}{35} \\
\hline \multirow[t]{2}{*}{ Neutralization } & Sodium Formiate & 1.5 & & \\
\hline & Sodium Bicarbonate & 0.5 & & \\
\hline \multicolumn{5}{|c|}{$\mathrm{pH}$ Control ( 6) and drain } \\
\hline \multirow[t]{2}{*}{ Washing } & Water & 300 & \multirow[t]{2}{*}{10} & \multirow[t]{2}{*}{40} \\
\hline & & Drain & & \\
\hline \multirow{3}{*}{ Retanning } & Water & 200 & \multirow{3}{*}{120} & \multirow{3}{*}{40} \\
\hline & Vegetable Extract & 12 & & \\
\hline & & add & & \\
\hline \multirow{2}{*}{ Dyeing } & Water & 50 & \multirow{2}{*}{30} & \multirow{2}{*}{50} \\
\hline & Dyestuff & 2 & & \\
\hline \multirow{5}{*}{ Fat-liquoring } & & add & & \\
\hline & Indinol BE & 2 & \multirow{5}{*}{60} & \multirow{5}{*}{50} \\
\hline & Indinol HS & 3 & & \\
\hline & Indinol EAF & 3 & & \\
\hline & Indinol LOX & 4 & & \\
\hline \multicolumn{3}{|r|}{ add } & & \\
\hline Fixation & Formic Acid & 1 & 30 & 50 \\
\hline \multicolumn{5}{|c|}{$\mathrm{pH}$ Control (4.2) and drain } \\
\hline Washing & Water & 300 & 10 & 25 \\
\hline \multicolumn{5}{|c|}{ Squeeze, Dry and Stacked } \\
\hline
\end{tabular}


After this process the hide pieces were squeezed, dried and stacked. Properties, as physical-mechanical tests according to ISO 3377:2002 for tear strength, and ISO 3379:1976 for ball burst test (to evaluate the grain cracking), and leather behavior regarding softness and grain firmness, were evaluated for the different leather pieces.

\section{RESULTS AND DISCUSSIONS}

\section{Vegetable Extracts Absorption}

Wet-white shaved pieces were treated with $12 \% \mathrm{w} / \mathrm{w}$ of vegetable extract according the process described above. Two replicas were done with natural chestnut in one case and two replicas with mimosa in the other case. Samples of the vegetable retanning bath were taken at $1 \mathrm{~min}, 15 \mathrm{~min}, 30 \mathrm{~min}, 60 \mathrm{~min}$ and $120 \mathrm{~min}$ of running time for reading the absorbance. Results for vegetable extract exhaustion in bath are shown in Figures 1 and 2.

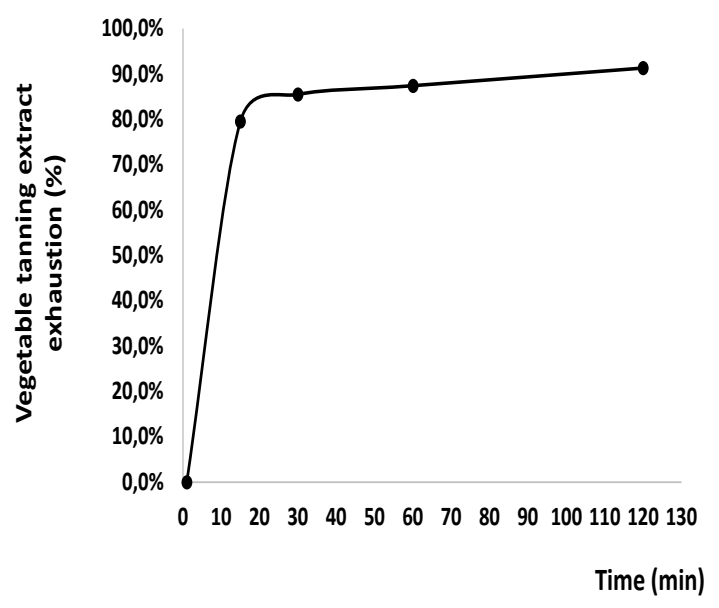

Figure 1. Wet-white absorption of natural chestnut extract

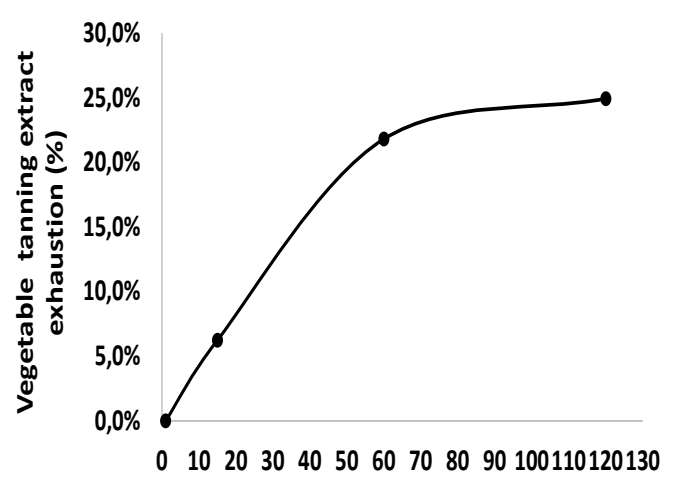

Time (min)

Figure 2. Wet-white absorption of Mimosa extract

From the figures it can be seen that the uptake is greater and faster in the case of natural chestnut. This indicates a better reactivity of natural chestnut extract comparing with mimosa extract. For a better up-take of mimosa extract it would be necessary more time.

Vegetable Effect on Leather: Physical and Mechanical Properties

A complete wet-end process was applied to wet-white shaved pieces in order to evaluate leather properties, as physical-mechanical tests according to ISO 3377:2002 for tear strength, and ISO 3379:1976 for ball burst test (to evaluate the grain cracking), and leather behavior regarding softness and grain firmness. Results for physicalmechanical tests are shown in Table 3. 
Table 3: Physical and Mechanical Tests

\begin{tabular}{cccc}
\hline & Tear Strength & \multicolumn{2}{c}{ Ball burst test } \\
Vegetable Extract & $(\mathrm{N})$ & Load (N) & Distension (mm) \\
\hline Tara & 325 & 579.3 & 9.2 \\
Cashew & 261 & 498.0 & 8.7 \\
Natural Chestnut & 270 & 510.9 & 8.2 \\
Mimosa & 202 & 247.0 & 7.8 \\
Sweetened Chestnut & 112 & 262.1 & 7.7 \\
Gambier & 179 & 200.8 & 7.1 \\
Quebracho & 121 & 282.0 & 8.0 \\
\hline
\end{tabular}

The results obtained, when compared with the reference values generally accepted for footwear application: $200 \mathrm{~N}$ for load and $7 \mathrm{~mm}$ for distension in ball burst test and $120 \mathrm{~N}$ for tear strength, are very good with evidence for tara extract.

The evaluation of the leather pieces obtained showed a good softness and grain firmness, in general, with a tendence for less softness in the case of tara, cashew and natural chestnut.

\section{CONCLUSIONS}

The aim of this work was the study of vegetable extracts effect on the retannage of wetwhite leather, produced by the glutaraldehide and syntan pre-tannage process, evaluating the bath exhaustion and physico-mechanical leather properties.

It was shown that the absorption of vegetable extracts by the leather was greater and faster for the hydrolysable tannins (natural chestnut vegetable extract) than for condensed tannins (mimosa vegetable extract). Hydrolysable tannins have a natural acidity that result in a high degree of tannin fixation comparing to condensed tannins and for this reason a better absorption was achieved.

Physical mechanical properties of leather were good satisfying the minimum required for footwear and characteristics as leather firmness and softness were good although tara, cashew and natural chestnut have generated some hardness. All the vegetable extracts can be used as retanning agents and the choice depends on the desired leather final product.

Nevertheless, a validation of these results at a larger scale will be important.

\section{Acknowledgements}

The authors would like to acknowledge QREN Portuguese National Program and IAPMEI for the support of the Project INDIWHITE.

\section{REFERENCES}

1. Tegtmeyer, D., Kleban, M., Chromium and leather research - A balanced view of scientific facts and figures, IULTCS, IUR-1 Aug 2013, pp. 1-10.

2. Sreeram, K.J., Ramasami, T., Resour Conserv Recycl, 2003, 38, 185-212, https://doi. org/10.1016/S0921-3449(02)00151-9.

3. Dasgupta, S., J Soc Leath Tech Ch, 2002, 86, 88-194.

4. Di, Y., Heat, R.J., Long, A., Hartnung, K., J Soc Leath Tech Ch, 2006, 90, 93-101.

5. Zhongbing, L., Xuepin, L., Bi, S., J Soc Leath Tech Ch, 2003, 87, 173-178.

6. Pu., S., Wang, Y., He, Q., Liao, X., Zhang, W., Shi, B., Int J Quantum Chem, 2012, 112, 2832- 
2839, https://doi.org/10.1002/qua.23300.

7. Kanth, S., Kannan, P., Usharani, N., Jayakumar,

G., Deepa, S., Chandrasekaran, B., J Am Leather Chem As, 2010, 105, 1, 16-24.

(C) 2018 by the author(s). Published by INCDTPICPI, Bucharest, RO. This is an open access article distributed under the terms and conditions of the Creative Commons Attribution license (http:// creativecommons.org/licenses/by/4.0/). 